\title{
Standard of care versus new-wave corticosteroids in the treatment of Duchenne muscular dystrophy: Can we do better?
}

Stephanie Kourakis ${ }^{1}$, Cara A. Timpani ${ }^{1,2}$, Dean G. Campelj ${ }^{1,2}$, Patricia Hafner ${ }^{3}$, Nuri Gueven ${ }^{4}$, Dirk Fischer ${ }^{3}$ and Emma Rybalka ${ }^{1,2^{*}}$

\begin{abstract}
Background: Pharmacological corticosteroid therapy is the standard of care in Duchenne Muscular Dystrophy (DMD) that aims to control symptoms and slow disease progression through potent anti-inflammatory action. However, a major concern is the significant adverse effects associated with long term-use.

Main: This review discusses the pros and cons of standard of care treatment for DMD and compares it to novel data generated with the new-wave dissociative corticosteroid, vamorolone. The current status of experimental anti-inflammatory pharmaceuticals is also reviewed, with insights regarding alternative drugs that could provide therapeutic advantage.

Conclusions: Although novel dissociative steroids may be superior substitutes to corticosteroids, other potential therapeutics should be explored. Repurposing or developing novel pharmacological therapies capable of addressing the many pathogenic features of DMD in addition to anti-inflammation could elicit greater therapeutic advantages.
\end{abstract}

Keywords: Duchenne muscular dystrophy, Corticosteroids, Standard of care, Anti-inflammatory drugs, Antiinflammation

\section{Background}

Pharmacological corticosteroid therapy is the standard of care in Duchenne Muscular Dystrophy (DMD), a progressive, genetically inherited neuromuscular diseases arising from mutations in the dystrophin gene. Null dystrophin protein expression compromises the stability and permeability of the sarcolemma and initiates chronic muscle damage, inflammation, degeneration and wasting, with death as an eventual outcome due to cardiorespiratory failure. With no cure, corticosteroid treatment aims to control symptoms and slow disease progression through potent anti-inflammatory action. Although the

\footnotetext{
*Correspondence: emma.rybalka@vu.edu.au

${ }^{1}$ Institute for Health and Sport (IHeS), Victoria University, Melbourne, VIC, Australia
}

Full list of author information is available at the end of the article clinical efficacy and short-term benefits of steroid use is established, of major concern are the significant adverse effects associated with long term-use. Although alternatives such as dissociative steroids are developed, nonsteroidal therapeutics with favourable side-effect profiles that can be rapidly translated into a clinical setting should also be investigated as alternatives to address the high unmet medical need in the treatment of DMD patients.

\section{Introduction}

Duchenne muscular dystrophy (DMD) is a X-linked recessive disorder that arises from mutations in the dystrophin gene causing absent or truncated dystrophin protein [1]. Approximately $60 \%$ of mutations arise from large deletion or insertion frameshift errors and $40 \%$ arise from small frameshift errors or point mutations [1]. Out of frame mutations usually result in the complete ablation original author(s) and the source, provide a link to the Creative Commons licence, and indicate if changes were made. The images or other third party material in this article are included in the article's Creative Commons licence, unless indicated otherwise in a credit line to the material. If material is not included in the article's Creative Commons licence and your intended use is not permitted by statutory regulation or exceeds the permitted use, you will need to obtain permission directly from the copyright holder. To view a copy of this licence, visit http://creativecommons.org/licenses/by/4.0/. The Creative Commons Public Domain Dedication waiver (http://creativeco mmons.org/publicdomain/zero/1.0/) applies to the data made available in this article, unless otherwise stated in a credit line to the data. 
of dystrophin protein expression (DMD) while in frame mutations usually result in partial dystrophin expression and Becker muscular dystrophy (BMD), a milder form of dystrophinopathy [2]. Designated a rare disease, DMD affects 1 in 3500-7000 live male births worldwide $[3,4]$. It is characterised by inflammation and progressive degeneration of skeletal and cardiac muscles $[1,5]$. The deterioration of ambulatory function arises initially during childhood and culminates in complete loss by early adolescence [6]. Further complications include scoliosis, contractures and cardiorespiratory decline, which over time contribute to death in early adulthood [4]. Therapies that target the underlying genetic mutations of DMD such as human micro-dystrophin gene delivery $[7,8]$ and antisense oligonucleotide exon skipping therapeutics [9, 10] offer a new avenue for a potential cure. However, long term clinical benefit has yet to be established for either. Presently, standard of care is corticosteroids (glucocorticoids), which aim to delay progression of the disease by reducing inflammation-induced muscle damage and thus muscle strength loss and disease progression [11].

Glucocorticoids diffuse through the cell membrane, binding to the cytoplasmic nuclear hormone receptor (glucocorticoid receptor (GR)) to form a receptor-ligand complex, which translocates to the nucleus $[12,13]$. The GR supresses the pro-inflammatory nuclear factor kappa $\mathrm{B}(\mathrm{NF}-\mathrm{kB})$ signalling pathway, to exert the well-known potent anti-inflammatory effects of steroids in a process termed transrepression [14, 15] (Fig. 1). NF-kB transcriptional activity is chronically elevated in DMD and is recognised as a key molecular feature of disease onset and progression [16, 17]. As well as strong transrepressor

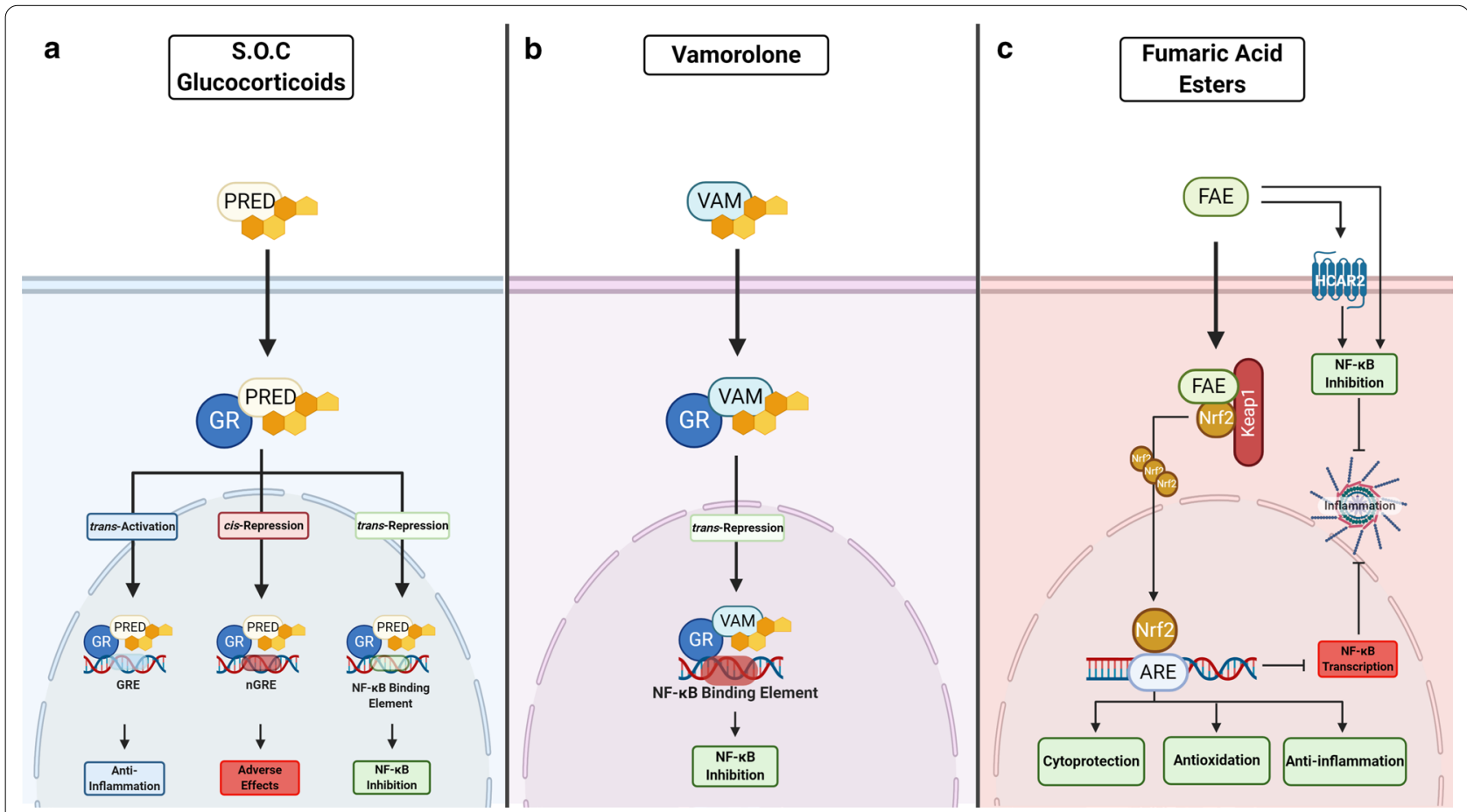

Fig. 1 Comparing the mechanisms of action of standard of care (S.O.C) glucocorticoids (i.e., prednisone and deflazacort) with novel dissociative steroid vamorolone and fumaric acid esters (FAE). a Glucocorticoids like prednisone (PRED), diffuse through the cell membrane, bind to the cytoplasmic nuclear hormone receptor (glucocorticoid receptor (GR)) to form a receptor-ligand complex, which translocates to the nucleus. This complex indirectly binds to the glucocorticoid response element (GRE), activating target genes that are associated with broad spectrum anti-inflammation (trans-activation), as well as the nuclear factor kappa B (NF-kB) binding element to supress transcription of master inflammatory regulator, NF-KB (trans-repression). These mechanisms elicit the beneficial effects of glucocorticoids in DMD. In contrast, adverse effects are mediated through direct binding of the GR-ligand complex to negative GRE on other target genes, which represses their transcription (cis-repression). b Similarly, vamorolone binds to the GR and retains the anti-inflammatory effects characteristic of standard of care glucocorticoids, inducing transrepression with hardly any transactivation or cis-repression to elicit fewer adverse effects. c Therapeutic efficacy of FAEs is mediated through the dual activation of the nuclear factor erythroid 2-related factor 2 (Nrf2) transcriptional pathway and hydroxycarboxylic acid receptor 2 (HCAR2). Nrf2 regulates the essential cellular defence system when electrophiles/FAE bind and disrupt the interaction between Nrf2 and its negative repressor (Kelch-like ECH-associated protein 1 (Keap1)). This disruption allows Nrf2 to translocate to the nucleus, bind to the antioxidant response element (ARE) resulting in cytoprotection. Nrf2 and HCAR2 both strongly inhibit NF-KB signalling within the cellular inflammatory response. Created with BioRender.com 
activity against NF- $\kappa \mathrm{B}$, the receptor-ligand complex also directly binds the glucocorticoid response element (GRE) to increase the transcription of target genes (e.g. nuclear factor of kappa light polypeptide gene enhancer in B-cells inhibitor, alpha (IкB $\alpha)$ a protein inhibitor of NF-kB, annexin 1, interleukin-10 (IL-10)) to elicit broad spectrum anti-inflammatory action in a process termed transactivation [15, 18] (Fig. 1). However, the GR receptor-ligand complex can also directly bind negative GRE sites (nGRE) on other target genes (e.g., corticotrophinreleasing hormone $(\mathrm{CRH})$, osteocalcin $(\mathrm{OC})$, proopiomelanocortin (POMC)) to supress gene transcription in a process called cis-repression [19, 20]. GR-mediated cis-repression is associated with the notorious adverse effects elicited by glucocorticoids (Fig. 1) including growth retardation/failure to thrive (CRH and POMC), osteoporosis (OC) and skin fragility (keratins) (for detailed reviews see $[19,20])$. Although glucocorticoids are routinely prescribed for DMD patients, questions still remain as to whether some of the more severe side effects (e.g., excessive weight gain, cataracts, behavioural issues, delayed growth and osteoporosis) contraindicate the intended benefits. This review compares the mechanism of action of commonly used and novel glucocorticoids together with their adverse effects, against pharmacological alternatives that may offer superior therapeutic benefit.

\section{Standard of Care in DMD}

Corticosteroids are a class of steroid hormones that are released by the adrenal cortex, which include glucocorticoids [21]. Glucocorticoids bind to and activate the GR [12], regulating several physiological processes including immune response [22, 23], metabolism [24], mood and cognitive function [25]. Pharmacological analogues (e.g. prednisone and dexamethasone) are often prescribed for auto-immune and inflammatory diseases because of their considerable immuno-modulatory properties [23, 26 ] and have become a clinical mainstay, especially in the treatment of DMD. However, the therapeutic benefits of glucocorticoids are limited by several adverse effects associated with their long-term use.

The glucocorticoids prednisone/prednisolone and deflazacort are the gold standard of care for the treatment of DMD [27]. Prednisone is a synthetic, anti-inflammatory glucocorticoid, which is converted to prednisolone in the liver [28]. Prednisone was approved by the Food and Drug Administration (FDA) in the 1950s and is prescribed as a dual immunosuppressive and anti-inflammatory agent to treat a broad range of conditions including, but not limited to, rheumatic [26, 29, 30], dermatologic [31], ophthalmic [32, 33], respiratory [34, 35], hematologic [36] and gastrointestinal [37, 38] indications.
Prednisone/prednisolone is currently used off-label for DMD to slow progressive muscle weakness and delay associated disease milestones (e.g. Gowers' manoeuvre, loss of ambulation and nocturnal ventilation) [39, 40].

In DMD, the absence of dystrophin causes muscle fibres to become vulnerable to contraction-induced damage prompting them to undergo repeated cycles of necrosis and regeneration until muscle mass is progressively replaced by fibrous connective tissue and fat resulting in muscle weakness and loss of function [41]. It was suggested that prednisone slows progression of muscle weakness $[40,42-44]$ and in doing so prolongs ambulation for 2-3 years [45-47] and improves pulmonary function $[48,49]$. This function seems particularly relevant to early intervention i.e. from $2-4$ years of age [50]. Unfortunately, high dosage or long-term use of prednisone is typically accompanied by mild to severe adverse effects that can impact the quality of life, reduce patient adherence and limit overall therapeutic outcomes in DMD sufferers. These include: excessive weight gain [40, 42, 48, 49, 51], adrenal insufficiency [52], stunted growth [51], cushingoid appearance [48, 49], behavioural changes [53], decreased bone mineral density [54] and increased incidence of fractures $[46,55]$. These adverse effects, in combination with the already progressive, terminal nature of DMD may further place undue strain on patients and their families, and in particular, increase parental stress. For this reason, short-term intermittent prednisone treatment has been investigated as an alternative to chronic therapy, with noticeably reduced adverse effects and family stress and no impact on therapeutic activity [40].

Deflazacort, an oxazoline derivative of prednisolone [56] was approved in 2017 for DMD patients aged 5 years and older. Similar to prednisone, deflazacort is also used to treat a variety of other diseases based on its anti-inflammatory and immunosuppressive effects. Deflazacort shows comparable efficacy to prednisone in DMD patients but has been associated with improved outcomes such as greater delay in loss of ambulation [46, $47,57-59]$, cardiac, pulmonary and motor function [46, $58-60]$ and a lower risk of scoliosis $[46,47]$ in contrast to prednisone/prednisolone [59]. Deflazacort is purported as a steroid alternative with fewer adverse effects and possibly with less risk of weight gain compared to prednisone $[46,47,58,61]$. However, in comparison to prednisone it is associated with behavioural changes [53] and cataract formation $[46,47,57,58]$. The effects of deflazacort on development and bone health have been inconsistent. Balaban (2005), Marden (2020), Bello (2015) and Biggar (2001) associated deflazacort with higher frequencies of growth delay and bone fractures $[46,47,57,58]$ whereas Mesa (1991) and Angelini (1994) reported fewer 
effects on bone mass and fractures $[60,62]$ in comparison to prednisone, making it unclear how deflazacort affects bone health.

The cardiac effects of corticosteroid treatment in DMD patients are not well characterised, although their use was associated with benefits such as improved overall cardiac function and delayed onset of cardiomyopathy [63-65]. Conversely, other studies indicated that patients who commence corticosteroid treatment at an early age $(<5$ years old) are more likely to develop premature onset of cardiomyopathy compared to those who initiate treatment in later childhood as well as those who do not undergo treatment [66]. Long-term administration of glucocorticoids has also been associated with acceleration of protein breakdown and inhibition of protein synthesis [67-69], which may ultimately lead to skeletal muscle atrophy [70-72]. These catabolic effects appear to be mediated, at least in part, via modulation of insulinlike growth factor-1 (IGF-1) signalling and pro-atrophy signalling through Atrogin-1 [69, 73]. Despite atrophy being counterintuitive to the attenuation of muscle wasting, glucocorticoids are still able to ablate some clinical symptoms through anti-inflammatory function. While these studies contributed to our understanding concerning the impact of corticosteroid treatment on DMD patients, some are disadvantaged by their short duration and follow-up times highlighting the need for longitudinal studies to understand the full impact of long-term corticosteroid use. Although there is ongoing research to establish the most effective dose and regimens for glucocorticoids, safer alternatives are needed that offer a better benefit to side effect profile. In this regard, a novel dissociative steroid has recently shown some promise.

\section{Vamorolone: a novel dissociative steroid}

Vamorolone (formerly VBP-15), is a first-in-class antiinflammatory steroid analogue [74] that is currently being investigated as a replacement for traditional standard of care glucocorticoids in DMD. The structure of vamorolone is similar to other glucocorticoids: it binds to the GR and retains the anti-inflammatory effects characteristic of traditional steroids, preferentially inducing transrepression with little-to-no transactivation or cisrepression (Fig. 1). As such, it is purported to elicit fewer adverse effects $[13,75]$. Vamorolone is also a mineralocorticoid receptor (MR) antagonist [18], and thus has the potential to treat DMD-associated cardiomyopathy through modulation of blood pressure. Dystrophin-deficient hearts are especially sensitive to damage facilitated through MR activation [18] although specific MR antagonists (e.g., spirololactone) showed no pre-clinical efficacy when administered with an angiotensin converting enzyme inhibitor drug in $m d x$ mice with exacerbated disease [76]. The development of vamorolone for DMD was initiated with a Phase I clinical trial (NCT02415439) in healthy volunteers to assess its safety, tolerability and pharmacokinetics. Vamorolone was well-tolerated at all dose levels, with pharmacokinetic and metabolic profiles similar to that of prednisone but without the associated adverse effects and safety concerns of traditional glucocorticoids (e.g., dexamethasone and prednisone) [77]. Subsequently, a Phase IIa trial in DMD boys aged 4 to $<7$ years (NCT02760277) investigated safety and tolerability of a range of vamorolone doses and explored potential efficacy over 6 months. Similar to the Phase I trial, Vamorolone was reported to be safe and well-tolerated and met the primary efficacy outcome of improved muscle function without evidence of adverse effects $[78,79]$. Rather than transition back to glucocorticoids, all patients included in the study requested to continue treatment on vamorolone under the 24-month long-term open-label extension study (NCT03038399), which was recently completed [80]. In this study, treatment with vamorolone was associated with improvements in some motor outcomes and a favourable safety profile as fewer adverse effects were reported (less incidence of weight gain, behavioural changes and cushingoid appearance) [80] compared to those previously reported with traditional corticosteroid use. Importantly, vamorolone, did not repress growth, which is usually observed with SOC treatment. An ongoing Phase IIb randomised, doubleblind trial (NCT03439670) is designed to demonstrate efficacy and safety of vamorolone at different doses compared to prednisone and placebo over 24 weeks. Based on the available data, vamorolone received orphan drug status in the United States and Europe and will likely establish itself as a safer and superior alternative to current SOC glucocorticoids to benefit DMD patients (as well as patients diagnosed with other chronic inflammatory diseases).

\section{Pharmacological anti-inflammatory alternatives for DMD}

Despite some advances, an unmet clinical need remains for DMD disease-modifying drugs that are well tolerated and effectively mitigate disease progression. Steroids have prevailed as the only disease modifying drugs against DMD for more than a decade, despite their propensity to promote muscular atrophy [70-72]. Presumably, their intense anti-inflammatory function is more influential to attenuate muscle wasting than their atrophic effect progresses it [81]. Particularly, chronic inflammation is a driver of fast type II muscle fibre loss, which is pronounced in DMD [82]. It is possible that other potent anti-inflammatory drugs could have equivalent, if not greater, beneficial effects on mitigating DMD without the associated side-effects-particularly those pertaining to 
muscle atrophy, which is clearly counterintuitive in DMD treatment.

Many anti-inflammatory drugs have been tested preclinically (typically in the $m d x$ mouse) and while a few have recently undergone clinical testing (the covalentlylinked salicylic acid and docosahexaenoic acid small molecule, edasalonexent/CAT-1004: NCT02439216, NCT03703882 [83, 84]; and the tetracosactide (cosyntrophin) formulation synthetic melanocortin receptor agonist, MNK-1411: NCT03400852 [85]), their clinical development was terminated due to lack of efficacy and/ or recruitment issues. There are a variety of other potent anti-inflammatory drugs on the market that are yet to be investigated in DMD and that could be therapeutically advantageous compared to the glucocorticoids. Fumaric acid esters (FAEs) such as dimethyl fumarate (DMF), monomethyl fumarate (MMF) and diroximel fumarate (DRF) are well-known for their anti-inflammatory and immuno-modulatory effects [86-89]. FAEs are presently approved for several indications including psoriasis and Remitting-Relapsing Multiple Sclerosis (RRMS) [90-93]. These drugs display robust safety profiles and comprehensive clinical utility for diseases characterised by inflammation and oxidative stress, and both of these are notorious drivers of DMD [94-102]. The therapeutic efficacy of FAEs appear to be mediated through the dual activation of the nuclear factor erythroid 2-related factor 2 (Nrf2) transcriptional pathway [88, 103-105] and the hydroxycarboxylic acid receptor 2 (HCAR2) [106, 107] (Fig. 1). Nrf2 regulates the essential cellular defence system that counteracts potentially harmful stimuli through the upregulation of antioxidants and cytoprotective response genes $[108,109]$. Both Nrf2 and HCAR2 also strongly inhibit NF- $\mathrm{kB}$ signalling of the cellular inflammatory response [106, 110, 111]. Over the last decade, several Nrf2 activating drugs have been developed and trialled in both clinical [112-117] and pre-clinical [118121] settings highlighting the broad therapeutic utility of targeted Nrf2 activation against diseases associated with inflammation and oxidative stress [122]. There are many pharmacological as well as nutraceutical activators of Nrf2 including those approved for use as disease modifying treatments (DMF, MMF, DRF, ursodiol and oltipraz). Whilst no clinical trials have investigated FAEs for their dual Nrf2/HCAR2 activator action in DMD patients at present [123], the synthetic flavonone, epicatechin, which has strong anti-inflammatory properties [124, 125] and is an Nrf2 activator [126] (in addition to several other purported mechanisms of action such as myostatin suppression), has tested favourably in the $m d x$ mouse [127, 128] and is in clinical development for BMD (NCT04386304) [129] (but not DMD). Given the safety and efficacy of FAEs and targeted Nrf2 activators established in other studies, further translational investigations should be undertaken to assess the therapeutic potential of novel and repurposed modulators of DMD pathology as corticosteroid alternatives. This is particularly relevant since Nrf2 activation has additional benefits beyond the antiinflammatory activity of glucocorticoids, which include energy re-balancing through mitochondrial biogenesis as well as muscle regeneration and repair [123]. Through multiple mechanisms, FAEs can also modify a more extensive cytokine profile than glucocorticoids [130].

\section{Conclusion}

In DMD, glucocorticoids represent the most frequently used drug class for the management of symptoms. However, the current standard of care (prednisone/ prednisolone or deflazacort) acts non-selectively [131] contributing to many associated complications which impact quality of life. More recently, research has focused on novel selective, dissociative steroids, such as vamorolone [74, 77-79], which may provide a better alternative by reducing steroid-associated adverse effects. Although novel dissociative steroids may be a superior substitute to glucocorticoids, other potential therapeutics should be explored. Repurposing or developing novel pharmacological therapies that are capable of addressing the many downstream consequences of dystrophin deficiency, such as FAEs and novel Nrf2 activators, respectively, may be a viable option to improve patient quality of life without severe adverse events like those observed with corticosteroid use. Since they activate alternative receptors/signalling pathways to glucocorticoids, there is also scope for combined FAE and corticosteroid regimens that could synergistically amplify therapeutic potential.

\section{Abbreviations \\ DMD: Duchenne Muscular Dystrophy; GR: Glucocorticoid Receptor; NF-kB: Nuclear Factor kappa B; GRE: Glucocorticoid Response Element; Ik-Ba: Nuclear Factor of Kappa Light Polypeptide Gene Enhancer in B-cells Inhibi- tor, Alpha; FDA: Food and Drug Administration; IGF-1: Insulin-like Growth Factor 1; MR: Mineralocorticoid Receptor; DHA: Docosahexaenoic Acid; FAEs: Fumaric Acid Esters; DMF: Dimethyl Fumarate; MMF: Monomethyl Fumarate; DRF: Diroximel Fumarate; RRMS: Relapsing-remitting Multiple Sclerosis; Nrf2: Nuclear factor erythroid 2-Related Factor 2; HCAR2: Hydroxycarboxylic Acid Receptor 2.}

\section{Acknowledgements}

Not applicable.

\section{Authors' contributions}

S.K., C.A.T. and E.R. wrote the manuscript. All authors read and approved the final manuscript.

Funding

Not applicable.

Availability of data and materials Not applicable. 


\section{Ethics approval and consent to participate}

Not applicable.

\section{Consent for publication}

Not applicable.

\section{Competing interests}

E.R. and N.G. are consultants to Santhera Pharmaceuticals. E.R. is a consultant to Epirium Bio. D.F. is a principal investigator for studies on spinal muscular atrophy sponsored by Hofmann-La Roche Ltd. The other authors have no interests to declare.

\section{Author details}

${ }^{1}$ Institute for Health and Sport (IHeS), Victoria University, Melbourne, VIC, Australia. ${ }^{2}$ Australian Institute for Musculoskeletal Science (AIMSS), St Albans, VIC, Australia. ${ }^{3}$ Division of Neuropediatrics and Developmental Medicine, University Children's Hospital of Basel (UKBB), Basel, Switzerland. ${ }^{4}$ School of Pharmacy and Pharmacology, University of Tasmania, Hobart, TAS, Australia.

\section{Received: 22 December 2020 Accepted: 18 February 2021}

\section{Published online: 04 March 2021}

\section{References}

1. Nowak KJ, Davies KE. Duchenne muscular dystrophy and dystrophin: pathogenesis and opportunities for treatment. EMBO Rep. 2004;5:872-6.

2. Nicolas A, Lucchetti-Miganeh C, Yaou RB, Kaplan J-C, Chelly J, Leturca F, Barloy-Hubler F, Le Rumeur E. Assessment of the structural and functional impact of in-frame mutations of the DMD gene, using the tools included in the eDystrophin online database. Orphanet J Rare Dis. 2012;7:45.

3. Aartsma-Rus A, Ginjaar IB, Bushby K. The importance of genetic diagnosis for Duchenne muscular dystrophy. J Med Genet. 2016;53:145-51.

4. Walter MC, Reilich P. Recent developments in Duchenne muscular dystrophy: facts and numbers. J Cachexia Sarcopenia Muscle. 2017;8:681-5.

5. Ryder S, Leadley RM, Armstrong N, Westwood M, de Kock S, Butt T, Jain M, Kleijnen J. The burden, epidemiology, costs and treatment for Duchenne muscular dystrophy: an evidence review. Orphanet J Rare Dis. 2017:12:79.

6. Hoffman EP, Brown RH Jr, Kunkel LM. Dystrophin: the protein product of the Duchenne muscular dystrophy locus. Cell. 1987:51:919-28.

7. Mendell JR, Sahenk Z, Lehman K, Nease C, Lowes LP, Miller NF, lammarino MA, Alfano LN, Nicholl A, Al-Zaidy S, Lewis S, Church K, Shell R, Cripe LH, Potter RA, Griffin DA, Pozsgai E, Dugar A, Hogan M and Rodino-Klapac LR. Assessment of Systemic Delivery of rAAVrh74.MHCK7. micro-dystrophin in Children With Duchenne Muscular Dystrophy: A Nonrandomized Controlled Trial. JAMA Neurol. 2020;77:1122-1131.

8. Duan D. Micro-Dystrophin Gene Therapy Goes Systemic in Duchenne Muscular Dystrophy Patients. Hum Gene Ther. 2018;29:733-6.

9. Scaglioni D, Catapano F, Ellis M, Torelli S, Chambers D, Feng L, Beck M, Sewry C, Monforte M, Harriman S, Koenig E, Malhotra J, Popplewell L, Guglieri M, Straub V, Mercuri E, Servais L, Phadke R, Morgan J, Muntoni F. The administration of antisense oligonucleotide golodirsen reduces pathological regeneration in patients with Duchenne muscular dystrophy. Acta Neuropathologica Commun. 2021;9:7.

10. Echevarría L, Aupy P, Goyenvalle A. Exon-skipping advances for Duchenne muscular dystrophy. Hum Mol Genet. 2018;27:R163-72.

11. Kim S, Campbell KA, Fox DJ, Matthews DJ, Valdez R and STARnet MD Corticosteroid Treatments in Males With Duchenne Muscular Dystrophy: Treatment Duration and Time to Loss of Ambulation. J Child Neurol. 2015;30:1275-1280.

12. Oakley RH, Cidlowski JA. The biology of the glucocorticoid receptor: new signaling mechanisms in health and disease. J Allergy Clin Immunol. 2013;132:1033-44.

13. Heier CR, Damsker JM, Yu Q, Dillingham BC, Huynh T, Van der Meulen $J \mathrm{H}$, Sali A, Miller BK, Phadke A, Scheffer L, Quinn J, Tatem K, Jordan S, Dadgar S, Rodriguez OC, Albanese C, Calhoun M, Gordish-Dressman H, Jaiswal JK, Connor EM, McCall JM, Hoffman EP, Reeves EKM, Nagaraju
K. VBP15, a novel anti-inflammatory and membrane-stabilizer, improves muscular dystrophy without side effects. EMBO Mol Med. 2013;5:1569-85.

14. Petta I, Bougarne N, Vandewalle J, Dejager L, Vandevyver S, Ballegeer M, Desmet S, Thommis J, De Cauwer L, Lievens S, Libert C, Tavernier J, De Bosscher K. Glucocorticoid Receptor-mediated transactivation is hampered by Striatin-3, a novel interaction partner of the receptor. Sci Rep. 2017;7:8941.

15. Reeves EKM, Hoffman EP, Nagaraju K, Damsker JM, McCall JM. VBP15: preclinical characterization of a novel anti-inflammatory delta 9,11 steroid. Bioorg Med Chem. 2013;21:2241-9.

16. Messina S, Vita GL, Aguennouz M, Sframeli M, Romeo S, Rodolico C, Vita G. Activation of NF-kappaB pathway in Duchenne muscular dystrophy: relation to age. Acta Myol. 2011;30:16-23.

17. Peterson JM, Wang DJ, Shettigar V, Roof SR, Canan BD, Bakkar N, Shintaku J, Gu JM, Little SC, Ratnam NM, Londhe P, Lu L, Gaw CE, Petrosino JM, Liyanarachchi S, Wang H, Janssen PML, Davis JP, Ziolo MT, Sharma SM, Guttridge DC. NF-kB inhibition rescues cardiac function by remodeling calcium genes in a Duchenne muscular dystrophy model. Nat Commun. 2018;9:3431.

18. Heier CR, Yu Q, Fiorillo AA, Tully CB, Tucker A, Mazala DA, Uaesoontrachoon K, Srinivassane S, Damsker JM, Hoffman EP, Nagaraju K, Spurney CF. Vamorolone targets dual nuclear receptors to treat inflammation and dystrophic cardiomyopathy. Life Sci Alliance. 2019;2:e201800186.

19. Barnes PJ. Corticosteroid effects on cell signalling. Eur Respir J. 2006;27:413.

20. Dostert A, Heinzel T. Negative glucocorticoid receptor response elements and their role in glucocorticoid action. Curr Pharm Des. 2004;10:2807-16.

21. van Staa TP, Leufkens HG, Abenhaim L, Begaud B, Zhang B, Cooper C. Use of oral corticosteroids in the United Kingdom. QJM. 2000;93:105-11.

22. Coutinho AE, Chapman KE. The anti-inflammatory and immunosuppressive effects of glucocorticoids, recent developments and mechanistic insights. Mol Cell Endocrinol. 2011;335:2-13.

23. Strehl C, Ehlers L, Gaber T, Buttgereit F. Glucocorticoids-All-Rounders Tackling the Versatile Players of the Immune System. Front Immunol. 2019;10:1744-1744.

24. David PM, Shareen F, Brian RW. Glucocorticoids and fatty acid metabolism in humans: fuelling fat redistribution in the metabolic syndrome. J Endocrinol. 2008;197:189-204.

25. Marques AH, Silverman MN and Sternberg EM. Glucocorticoid dysregulations and their clinical correlates. From receptors to therapeutics. Ann NY Acad Sci. 2009;1179:1-18.

26. van der Goes MC, Jacobs JW, Bijlsma JW. The value of glucocorticoid co-therapy in different rheumatic diseases - positive and adverse effects. Arthritis Res Ther. 2014;16:S2

27. Gloss D, Moxley RT 3rd, Ashwal S, Oskoui M. Practice guideline update summary: Corticosteroid treatment of Duchenne muscular dystrophy: Report of the Guideline Development Subcommittee of the American Academy of Neurology. Neurology. 2016;86:465-72.

28. Powell LW, Axelsen E. Corticosteroids in liver disease: Studies on the biological conversion of prednisone to prednisolone and plasma protein binding. Gut. 1972;13:690.

29. Straub RH and Cutolo M. Glucocorticoids and chronic inflammation. Rheumatology. 2016;55:ii6-ii14.

30. Hua C, Buttgereit F, Combe B. Glucocorticoids in rheumatoid arthritis: current status and future studies. RMD Open. 2020;6:e000536.

31. Das A, Panda S. Use of Topical Corticosteroids in Dermatology: An Evidence-based Approach. Indian J Dermatol. 2017;62:237-50.

32. Sulaiman RS, Kadmiel M, Cidlowski JA. Glucocorticoid receptor signaling in the eye. Steroids. 2018;133:60-6.

33. Cutolo CA, Barabino S, Bonzano C, Traverso CE. The Use of Topical Corticosteroids for Treatment of Dry Eye Syndrome. Ocul Immunol Inflamm. 2019;27:266-75.

34. Falk JA, Minai OA, Mosenifar Z. Inhaled and systemic corticosteroids in chronic obstructive pulmonary disease. Proc Am Thorac Soc. 2008;5:506-12.

35. Adcock IM, Ito K. Glucocorticoid Pathways in Chronic Obstructive Pulmonary Disease Therapy. Proc Am Thorac Soc. 2005;2:313-9. 
36. Fardet L, Nazareth I, Petersen I. Synthetic Glucocorticoids and Early Variations of Blood Pressure: A Population-Based Cohort Study. J Clin Endocrinol Metab. 2015;100:2777-83.

37. Dubois-Camacho K, Ottum PA, Franco-Muñoz D, De la Fuente M, Torres-Riquelme A, Díaz-Jiménez D, Olivares-Morales M, Astudillo G, Quera R, Hermoso MA. Glucocorticosteroid therapy in inflammatory bowel diseases: From clinical practice to molecular biology. World J Gastroenterol. 2017;23:6628-38.

38. Waljee AK, Wiitala WL, Govani S, Stidham R, Saini S, Hou J, Feagins LA, Khan N, Good CB, Vijan S, Higgins PDR. Corticosteroid Use and Complications in a US Inflammatory Bowel Disease Cohort. PLoS ONE. 2016;11:e0158017-e0158017.

39. Angelini C, Peterle E. Old and new therapeutic developments in steroid treatment in Duchenne muscular dystrophy. Acta Myol. 2012;31:9-15

40. Beenakker EA, Fock JM, Van Tol MJ, Maurits NM, Koopman HM Brouwer OF, Van der Hoeven JH. Intermittent prednisone therapy in Duchenne muscular dystrophy: a randomized controlled trial. Arch Neurol. 2005;62:128-32.

41. Kharraz Y, Guerra J, Pessina P, Serrano AL, Muñoz-Cánoves P. Understanding the process of fibrosis in Duchenne muscular dystrophy. Biomed Res Int. 2014;2014:965631-965631.

42. Bäckman E, Henriksson KG. Low-dose prednisolone treatment in Duchenne and Becker muscular dystrophy. Neuromuscul Disord. 1995;5:233-41.

43. Pradhan S, Ghosh D, Srivastava NK, Kumar A, Mittal B, Pandey CM, Singh U. Prednisolone in Duchenne muscular dystrophy with imminent loss of ambulation. J Neurol. 2006;253:1309-16.

44. Fenichel GM, Florence JM, Pestronk A, Mendell JR, Moxley RT 3rd, Griggs RC, Brooke MH, Miller JP, Robison J, King W, et al. Long-term benefit from prednisone therapy in Duchenne muscular dystrophy. Neurology. 1991;41:1874-7.

45. DeSilva S, Drachman DB, Mellits D, Kuncl RW. Prednisone treatment in Duchenne muscular dystrophy. Long-term benefit Arch Neurol. 1987:44:818-22.

46. Balaban B, Matthews DJ, Clayton GH, Carry T. Corticosteroid treatment and functional improvement in Duchenne muscular dystrophy: long-term effect. Am J Phys Med Rehabil. 2005:84:843-50.

47. Marden JR, Freimark J, Yao Z, Signorovitch J, Tian C, Wong BL. Realworld outcomes of long-term prednisone and deflazacort use in patients with Duchenne muscular dystrophy: experience at a single, large care center. Journal of Comparative Effectiveness Research. 2020;9:177-89

48. Mendell JR, Moxley RT, Griggs RC, Brooke MH, Fenichel GM, Miller JP, King W, Signore L, Pandya S, Florence J, et al. Randomized, double-blind six-month trial of prednisone in Duchenne's muscular dystrophy. N Engl J Med. 1989;320:1592-7.

49. Griggs RC, Moxley RT, 3rd, Mendell JR, Fenichel GM, Brooke MH, Pestronk A and Miller JP. Prednisone in Duchenne dystrophy. A randomized, controlled trial defining the time course and dose response. Clinical Investigation of Duchenne Dystrophy Group. Arch Neurol. 1991;48:383-8.

50. Merlini L, Cicognani A, Malaspina E, Gennari M, Gnudi S, Talim B, Franzoni E. Early prednisone treatment in Duchenne muscular dystrophy. Muscle Nerve. 2003;27:222-7.

51. Griggs RC, Moxley RT 3rd, Mendell JR, Fenichel GM, Brooke MH, Pestronk A, Miller JP, Cwik VA, Pandya S, Robison J, et al. Duchenne dystrophy: randomized, controlled trial of prednisone (18 months) and azathioprine (12 months). Neurology. 1993;43:520-7.

52. Bowden SA, Connolly AM, Kinnett K, Zeitler PS. Management of Adrenal Insufficiency Risk After Long-term Systemic Glucocorticoid Therapy in Duchenne Muscular Dystrophy: Clinical Practice Recommendations. J Neuromuscul Dis. 2019;6:31-41.

53. Sienko S, Buckon C, Fowler E, Bagley A, Staudt L, Sison-Williamson M, Zebracki K, McDonald CM and Sussman M. Prednisone and Deflazacort in Duchenne Muscular Dystrophy: Do They Play a Different Role in Child Behavior and Perceived Quality of Life? PLoS currents. 2016;8:ecurrents. md.7628d9c014bfa29f821a5cd19723bbaa.

54. Bianchi ML, Mazzanti A, Galbiati E, Saraifoger S, Dubini A, Cornelio F, Morandi L. Bone mineral density and bone metabolism in Duchenne muscular dystrophy. Osteoporos Int. 2003;14:761-7.
55. Bothwell JE, Gordon KE, Dooley JM, Mac Sween J, Cummings EA, Salisbury S. Vertebral Fractures in Boys with Duchenne Muscular Dystrophy. Clin Pediatr. 2003:42:353-6.

56. Wood ML, Gray RES, Kanis JA, Harrington Cl. Deflazacort-a safer systemic steroid for the treatment of chronic dermatoses. Br J Dermatol. 1985;113:34-5.

57. Bello L, Gordish-Dressman H, Morgenroth LP, Henricson EK, Duong T, Hoffman EP, Cnaan A, McDonald CM, Investigators C. Prednisone/ prednisolone and deflazacort regimens in the CINRG Duchenne Natural History Study. Neurology. 2015;85:1048-55.

58. Biggar WD, Gingras M, Fehlings DL, Harris VA, Steele CA. Deflazacort treatment of Duchenne muscular dystrophy. J Pediatr. 2001;138:45-50.

59. Shieh PB, McIntosh J, Jin F, Souza M, Elfring G, Narayanan S, Trifillis P, Peltz SW, McDonald CM, Darras BT and The Act Dmd Study G. Deflazacort versus prednisone/prednisolone for maintaining motor function and delaying loss of ambulation: A post HOC analysis from the ACT DMD trial. Muscle \& nerve. 2018;58:639-645.

60. Mesa LE, Dubrovsky AL, Corderi J, Marco P, Flores D. Steroids in Duchenne muscular dystrophy-deflazacort trial. Neuromuscul Disord. 1991;1:261-6.

61. Bonifati MD, Ruzza G, Bonometto P, Berardinelli A, Gorni K, Orcesi S, Lanzi G, Angelini C. A multicenter, double-blind, randomized trial of deflazacort versus prednisone in Duchenne muscular dystrophy. Muscle Nerve. 2000:23:1344-7.

62. Angelini C, Pegoraro E, Turella E, Intino MT, Pini A, Costa C. Deflazacort in Duchenne dystrophy: study of long-term effect. Muscle Nerve. 1994;17:386-91.

63. Barber BJ, Andrews JG, Lu Z, West NA, Meaney FJ, Price ET, Gray A, Sheehan DW, Pandya S, Yang M, Cunniff C. Oral corticosteroids and onset of cardiomyopathy in Duchenne muscular dystrophy. J Pediatr. 2013:163(1080-4):e1.

64. Houde S, Filiatrault M, Fournier A, Dubé J, D’Arcy S, Bérubé D, Brousseau Y, Lapierre G, Vanasse M. Deflazacort use in Duchenne muscular dystrophy: an 8-year follow-up. Pediatr Neurol. 2008;38:200-6.

65. Markham LW, Kinnett K, Wong BL, Woodrow Benson D, Cripe LH. Corticosteroid treatment retards development of ventricular dysfunction in Duchenne muscular dystrophy. Neuromuscul Disord. 2008;18:365-70.

66. Kim S, Zhu Y, Romitti PA, Fox DJ, Sheehan DW, Valdez R, Matthews D, Barber BJ. Associations between timing of corticosteroid treatment initiation and clinical outcomes in Duchenne muscular dystrophy. Neuromuscul Disord. 2017;27:730-7.

67. Olney RC. Mechanisms of impaired growth: effect of steroids on bone and cartilage. Horm Res. 2009;72(Suppl 1):30-5.

68. Mauras N. Can growth hormone counteract the catabolic effects of steroids? Horm Res. 2009;72(Suppl 1):48-54.

69. Schakman O, Gilson H, Kalista S, Thissen JP. Mechanisms of Muscle Atrophy Induced by Glucocorticoids. Hormone Research in Paediatrics. 2009;72(suppl 1):36-41.

70. Dekhuijzen PN, Gayan-Ramirez G, Bisschop A, de Bock V, Dom R, Bouillon R, Decramer M. Rat diaphragm contractility and histopathology are affected differently by low dose treatment with methylprednisolone and deflazacort. Eur Respir J. 1995;8:824-30.

71. Gupta A, Gupta Y. Glucocorticoid-induced myopathy: Pathophysiology, diagnosis, and treatment. Indian journal of endocrinology and metabolism. 2013;17:913-6.

72. Fappi A, Neves JC, Sanches LN, Massaroto ESPV, Sikusawa GY, Brandão TPC, Chadi G and Zanoteli E. Skeletal Muscle Response to Deflazacort, Dexamethasone and Methylprednisolone. Cells. 2019:8.

73. Frystyk J, Schou AJ, Heuck C, Vorum H, Lyngholm M, Flyvbjerg A, Wolthers OD. Prednisolone reduces the ability of serum to activate the IGF1 receptor in vitro without affecting circulating total or free IGF1. Eur J Endocrinol. 2013;168:1-8.

74. Li X, Conklin LS, van den Anker J, Hoffman EP, Clemens PR and Jusko WJ. Exposure-Response Analysis of Vamorolone (VBP15) in Boys With Duchenne Muscular Dystrophy. The Journal of Clinical Pharmacology. 2020;n/a.

75. Schäcke H, Schottelius A, Döcke W-D, Strehlke P, Jaroch S, Schmees N, Rehwinkel $\mathrm{H}$, Hennekes $\mathrm{H}$, Asadullah K. Dissociation of transactivation from transrepression by a selective glucocorticoid receptor agonist leads to separation of therapeutic effects from side effects. Proc Natl Acad Sci U S A. 2004;101:227-32. 
76. Lowe J, Kadakia FK, Zins JG, Haupt M, Peczkowski KK, Rastogi N, Floyd KT, Gomez-Sanchez EP, Gomez-Sanchez CE, Elnakish MT, Rafael-Fortney JA, Janssen PML. Mineralocorticoid Receptor Antagonists in Muscular Dystrophy Mice During Aging and Exercise. J Neuromuscul Dis. 2018;5:295-306.

77. Hoffman EP, Riddle V, Siegler MA, Dickerson D, Backonja M, Kramer WG, Nagaraju K, Gordish-Dressman H, Damsker JM, McCall JM. Phase 1 trial of vamorolone, a first-in-class steroid, shows improvements in side effects via biomarkers bridged to clinical outcomes. Steroids. 2018;134:43-52.

78. Hoffman EP, Schwartz BD, Mengle-Gaw LJ, Smith EC, Castro D, Mah JK, McDonald CM, Kuntz NL, Finkel RS, Guglieri M, Bushby K, Tulinius M, Nevo Y, Ryan MM, Webster R, Smith AL, Morgenroth LP, Arrieta A, Shimony M, Siener C, Jaros M, Shale P, McCall JM, Nagaraju K, van den Anker J, Conklin LS, Cnaan A, Gordish-Dressman H, Damsker JM, Clemens PR. Vamorolone trial in Duchenne muscular dystrophy shows doserelated improvement of muscle function. Neurology. 2019;93:e1312.

79. Conklin LS, Damsker JM, Hoffman EP, Jusko WJ, Mavroudis PD, Schwartz BD, Mengle-Gaw LJ, Smith EC, Mah JK, Guglieri M, Nevo Y, Kuntz N, McDonald CM, Tulinius M, Ryan MM, Webster R, Castro D, Finkel RS, Smith AL, Morgenroth LP, Arrieta A, Shimony M, Jaros M, Shale P, McCall JM, Hathout Y, Nagaraju K, van den Anker J, Ward LM, Ahmet A, Cornish MR, Clemens PR. Phase lla trial in Duchenne muscular dystrophy shows vamorolone is a first-in-class dissociative steroidal anti-inflammatory drug. Pharmacol Res. 2018;136:140-50.

80. Smith EC, Conklin LS, Hoffman EP, Clemens PR, Mah JK, Finkel RS, Guglieri M, Tulinius M, Nevo Y, Ryan MM, Webster R, Castro D, Kuntz NL, Kerchner L, Morgenroth LP, Arrieta A, Shimony M, Jaros M, Shale P, Gordish-Dressman H, Hagerty L, Dang UJ, Damsker JM, Schwartz BD, Mengle-Gaw LJ, McDonald CM. Efficacy and safety of vamorolone in Duchenne muscular dystrophy: An 18-month interim analysis of a nonrandomized open-label extension study. PLoS Med. 2020;17:e1003222.

81. Quattrocelli M, Barefield DY, Warner JL, Vo AH, Hadhazy M, Earley JU, Demonbreun AR, McNally EM. Intermittent glucocorticoid steroid dosing enhances muscle repair without eliciting muscle atrophy. J Clin Invest. 2017;127:2418-32.

82. Webster C, Silberstein L, Hays AP, Blau HM. Fast muscle fibers are preferentially affected in Duchenne muscular dystrophy. Cell. 1988;52:503-13.

83. Donovan JM, Zimmer M, Offman E, Grant T, Jirousek M. A Novel NF-KB Inhibitor, Edasalonexent (CAT-1004), in Development as a DiseaseModifying Treatment for Patients With Duchenne Muscular Dystrophy: Phase 1 Safety, Pharmacokinetics, and Pharmacodynamics in Adult Subjects. J Clin Pharmacol. 2017;57:627-39.

84. Finanger $E$, Vandenborne $K$, Finkel RS, Lee Sweeney $H$, Tennekoon $G$, Yum S, Mancini M, Bista P, Nichols A, Liu H, Fretzen A, Donovan JM. Phase 1 Study of Edasalonexent (CAT-1004), an Oral NF-KB Inhibitor, in Pediatric Patients with Duchenne Muscular Dystrophy. J Neuromuscul Dis. 2019;6:43-54.

85. Hamilton DD, Cotton BA. Cosyntropin as a diagnostic agent in the screening of patients for adrenocortical insufficiency. Clin Pharmacol. 2010;2:77-82

86. Moharregh-Khiabani D, Linker RA, Gold R, Stangel M. Fumaric Acid and its esters: an emerging treatment for multiple sclerosis. Curr Neuropharmacol. 2009;7:60-4.

87. Rostami Yazdi M, Mrowietz U. Fumaric acid esters. Clin Dermatol. 2008;26:522-6.

88. Akino N, Wada-Hiraike $\mathrm{O}$, Isono W, Terao $\mathrm{H}$, Honjo H, Miyamoto $\mathrm{Y}_{\text {, }}$ Tanikawa M, Sone K, Hirano M, Harada M, Hirata T, Hirota Y, Koga K, Oda K, Fujii T, Osuga Y. Activation of Nrf2/Keap1 pathway by oral Dimethylfumarate administration alleviates oxidative stress and age-associated infertility might be delayed in the mouse ovary. Reprod Biol Endocrinol. 2019;17:23.

89. Palte MJ, Wehr A, Tawa M, Perkin K, Leigh-Pemberton R, Hanna J, Miller C, Penner N. Improving the Gastrointestinal Tolerability of Fumaric Acid Esters: Early Findings on Gastrointestinal Events with Diroximel Fumarate in Patients with Relapsing-Remitting Multiple Sclerosis from the Phase 3, Open-Label EVOLVE-MS-1 Study. Adv Ther. 2019;36:3154-65.

90. Kappos L, Gold R, Miller DH, MacManus DG, Havrdova E, Limmroth V, Polman CH, Schmierer K, Yousry TA, Yang M, Eraksoy M, Meluzinova E, Rektor I, Dawson KT, Sandrock AW, O'Neill GN. Efficacy and safety of oral fumarate in patients with relapsing-remitting multiple sclerosis: a multicentre, randomised, double-blind, placebo-controlled phase Ilb study. The Lancet. 2008;372:1463-72.

91. Fox RJ, Miller DH, Phillips JT, Hutchinson M, Havrdova E, Kita M, Yang M, Raghupathi K, Novas M, Sweetser MT, Viglietta V, Dawson KT. PlaceboControlled Phase 3 Study of Oral BG-12 or Glatiramer in Multiple Sclerosis. N Engl J Med. 2012;367:1087-97.

92. Reszke R, Szepietowski JC. A safety evaluation of dimethyl fumarate in moderate-to-severe psoriasis. Expert Opin Drug Saf. 2020;19:373-80.

93. Mrowietz U, Altmeyer P, Bieber T, Röcken M, Schopf RE and Sterry W. Treatment of psoriasis with fumaric acid esters (Fumaderm ${ }^{\circledR}$ ). JDDG: Journal der Deutschen Dermatologischen Gesellschaft. 2007;5:716-717.

94. Ellrichmann G, Lee DH, Reick C, Arning L, Petrasch-Parwez E, Saft C, Gold R, Linker RA. B1 1 Targeting the Nrf2 pathway in Huntington's disease: fumaric acid esters as a new therapeutic option in neurodegeneration? J Neurol Neurosurg Psychiatry. 2010;81:A14.

95. Li S, Takasu C, Lau H, Robles L, Vo K, Farzaneh T, Vaziri ND, Stamos MJ, Ichii H. Dimethyl Fumarate Alleviates Dextran Sulfate Sodium-Induced Colitis, through the Activation of Nrf2-Mediated Antioxidant and Antiinflammatory Pathways. Antioxidants (Basel). 2020;9:354.

96. Abdelrahman RS, Abdel-Rahman N. Dimethyl fumarate ameliorates acetaminophen-induced hepatic injury in mice dependent of $\mathrm{Nrf}-2 /$ HO-1 pathway. Life Sci. 2019;217:251-60.

97. Grzegorzewska AP, Seta F, Han R, Czajka CA, Makino K, Stawski L, Isenberg JS, Browning JL, Trojanowska M. Dimethyl Fumarate ameliorates pulmonary arterial hypertension and lung fibrosis by targeting multiple pathways. Sci Rep. 2017;7:41605-41605.

98. Casili G, Cordaro M, Impellizzeri D, Bruschetta G, Paterniti I, Cuzzocrea S, Esposito E. Dimethyl Fumarate Reduces Inflammatory Responses in Experimental Colitis. J Crohns Colitis. 2016;10:472-83.

99. Nicolay JP, Müller-Decker K, Schroeder A, Brechmann M, Möbs M, Géraud C, Assaf C, Goerdt S, Krammer PH, Gülow K. Dimethyl fumarate restores apoptosis sensitivity and inhibits tumor growth and metastasis in CTCL by targeting NF-KB. Blood. 2016;128:805-15.

100. Takeda T, Tsubaki M, Asano R, Itoh T, Imano M, Satou T and Nishida S. Dimethyl fumarate suppresses metastasis and growth of melanoma cells by inhibiting the nuclear translocation of NF-kB. Journal of Dermatological Science. 2020.

101. Shakya A, Soni UK, Rai G, Chatterjee SS, Kumar V. Gastro-protective and Anti-stress Efficacies of Monomethyl Fumarate and a Fumaria indica Extract in Chronically Stressed Rats. Cell Mol Neurobiol. 2016;36:621-35.

102. Campolo M, Casili G, Biundo F, Crupi R, Cordaro M, Cuzzocrea S, Esposito E. The Neuroprotective Effect of Dimethyl Fumarate in an MPTP-Mouse Model of Parkinson's Disease: Involvement of Reactive Oxygen Species/Nuclear Factor-kB/Nuclear Transcription Factor Related to NF-E2. Antioxid Redox Signal. 2017;27:453-71.

103. Saidu NEB, Noé G, Cerles O, Cabel L, Kavian-Tessler N, Chouzenoux S, Bahuaud M, Chéreau C, Nicco C, Leroy K, Borghese B, Goldwasser F, Batteux F, Alexandre J. Dimethyl Fumarate Controls the NRF2/DJ-1 Axis in Cancer Cells: Therapeutic Applications. Mol Cancer Ther. 2017;16:529.

104. Hayashi G, Jasoliya M, Sahdeo S, Saccà F, Pane C, Filla A, Marsili A, Puorro G, Lanzillo R, Brescia Morra V, Cortopassi G. Dimethyl fumarate mediates Nrf2-dependent mitochondrial biogenesis in mice and humans. Hum Mol Genet. 2017:26:2864-73.

105. Arnold P, Mojumder D, Detoledo J, Lucius R, Wilms H. Pathophysiological processes in multiple sclerosis: focus on nuclear factor erythroid-2-related factor 2 and emerging pathways. Clin Pharmacol. 2014;6:35-42.

106. Parodi B, Rossi S, Morando S, Cordano C, Bragoni A, Motta C, Usai C, Wipke BT, Scannevin RH, Mancardi GL, Centonze D, Kerlero de Rosbo $\mathrm{N}$ and Uccelli A. Fumarates modulate microglia activation through a novel HCAR2 signaling pathway and rescue synaptic dysregulation in inflamed CNS. Acta Neuropathol. 2015;130:279-95.

107. Breuer J, Herich S, Schneider-Hohendorf T, Chasan Al, Wettschureck N, Gross CC, Loser K, Zarbock A, Roth J, Klotz L, Wiendl H, Schwab N. Dual action by fumaric acid esters synergistically reduces adhesion to human endothelium. Multiple Sclerosis Journal. 2017;24:1871-82.

108. Mathers J, Fraser JA, McMahon M, Saunders RD, Hayes JD and McLellan LI. Antioxidant and cytoprotective responses to redox stress. Biochem Soc Symp. 2004:157-76.

109. Baird L, Dinkova-Kostova AT. The cytoprotective role of the Keap1-Nrf2 pathway. Arch Toxicol. 2011;85:241-72. 
110. Wardyn JD, Ponsford AH, Sanderson CM. Dissecting molecular crosstalk between Nrf2 and NF-kB response pathways. Biochem Soc Trans. 2015;43:621-6.

111. Li W, Khor TO, Xu C, Shen G, Jeong W-S, Yu S, Kong A-N. Activation of Nrf2-antioxidant signaling attenuates NFkappaB-inflammatory response and elicits apoptosis. Biochem Pharmacol. 2008;76:1485-9.

112. McDermott MM, Leeuwenburgh C, Guralnik JM, Tian L, Sufit R, Zhao L, Criqui MH, Kibbe MR, Stein JH, Lloyd-Jones D, Anton SD, Polonsky TS, Gao Y, de Cabo R, Ferrucci L. Effect of Resveratrol on Walking Performance in Older People With Peripheral Artery Disease: The RESTORE Randomized Clinical Trial. JAMA Cardiol. 2017;2:902-7.

113. Nangaku M, Kanda H, Takama H, Ichikawa T, Hase H, Akizawa T. Randomized Clinical Trial on the Effect of Bardoxolone Methyl on GFR in Diabetic Kidney Disease Patients (TSUBAKI Study). Kidney International Reports. 2020;5:879-90.

114. Chin MP, Bakris GL, Block GA, Chertow GM, Goldsberry A, Inker LA, Heerspink HJL, O'Grady M, Pergola PE, Wanner C, Warnock DG, Meyer CJ. Bardoxolone Methyl Improves Kidney Function in Patients with Chronic Kidney Disease Stage 4 and Type 2 Diabetes: Post-Hoc Analyses from Bardoxolone Methyl Evaluation in Patients with Chronic Kidney Disease and Type 2 Diabetes Study. Am J Nephrol. 2018;47:40-7.

115. Braley TJ, Huber AK, Segal BM, Kaplish N, Saban R, Washnock-Schmid JM and Chervin RD. A randomized, subject and rater-blinded, placebocontrolled trial of dimethyl fumarate for obstructive sleep apnea. Sleep. 2018;41.

116. Creelan BC, Gabrilovich DI, Gray JE, Williams CC, Tanvetyanon T, Haura EB, Weber JS, Gibney GT, Markowitz J, Proksch JW, Reisman SA, McKee MD, Chin MP, Meyer CJ, Antonia SJ. Safety, pharmacokinetics, and pharmacodynamics of oral omaveloxolone (RTA 408), a synthetic triterpenoid, in a first-in-human trial of patients with advanced solid tumors. Onco Targets Ther. 2017;10:4239-50.

117. Doss JF, Jonassaint JC, Garrett ME, Ashley-Koch AE, Telen MJ, Chi J-T. Phase 1 Study of a Sulforaphane-Containing Broccoli Sprout Homogenate for Sickle Cell Disease. PLoS ONE. 2016;11:e0152895.

118. González-Reyes S, Guzmán-Beltrán S, Medina-Campos ON, PedrazaChaverri J. Curcumin Pretreatment Induces Nrf2 and an Antioxidant Response and Prevents Hemin-Induced Toxicity in Primary Cultures of Cerebellar Granule Neurons of Rats. Oxid Med Cell Longev. 2013;2013:801418.

119. Sun C-C, Li S-J, Yang C-L, Xue R-L, Xi Y-Y, Wang L, Zhao Q-L, Li D-J. Sulforaphane Attenuates Muscle Inflammation in Dystrophin-deficient mdx Mice via NF-E2-related Factor 2 (Nrf2)-mediated Inhibition of NF-kB Signaling Pathway. J Biol Chem. 2015;290:17784-95.

120. Kim EN, Lim JH, Kim MY, Ban TH, Jang I-A, Yoon HE, Park CW, Chang YS, Choi BS. Resveratrol, an Nrf2 activator, ameliorates aging-related progressive renal injury. Aging (Albany NY). 2018;10:83-99.
121. Li XN, Ma LY, Ji H, Qin YH, Jin SS, Xu LX. Resveratrol protects against oxidative stress by activating the Keap-1/Nrf2 antioxidant defense system in obese-asthmatic rats. Exp Ther Med. 2018;16:4339-48.

122. Kourakis S, Timpani CA, de Haan JB, Gueven N, Fischer D and Rybalka E. Dimethyl Fumarate and Its Esters: A Drug with Broad Clinical Utility? Pharmaceuticals. 2020;13.

123. Kourakis S, Timpani CA, de Haan JB, Gueven N, Fischer D, Rybalka E. Targeting Nrf2 for the treatment of Duchenne Muscular Dystrophy. Redox Biol. 2021;38:101803.

124. Fan F-Y, Sang L-X, Jiang M. Catechins and Their Therapeutic Benefits to Inflammatory Bowel Disease. Molecules. 2017;22:484.

125. Al-Sayed E, Abdel-Daim MM. Analgesic and anti-inflammatory activities of epicatechin gallate from Bauhinia hookeri. Drug Dev Res. 2018;79:157-64.

126. T LS, Rupasinghe HPV, Dellaire G and Xu Z. Regulation of Nrf2/ARE Pathway by Dietary Flavonoids: A Friend or Foe for Cancer Management? Antioxidants (Basel). 2020;9.

127. Ramirez-Sanchez I, De los Santos S, Gonzalez-Basurto S, Canto P, Mendoza-Lorenzo P, Palma-Flores C, Ceballos-Reyes G, Villarreal F, Zentella-Dehesa A and Coral-Vazquez R. (-)-Epicatechin improves mitochondrial-related protein levels and ameliorates oxidative stress in dystrophic $\delta$-sarcoglycan null mouse striated muscle. The FEBS Journal. 2014;281:5567-5580.

128. Estrada-Mena FJ, Rodriguez A, Mendoza-Lorenzo P, Neri-GomezT, Manjarrez-Gutierrez G, Perez-Ortiz AC, Ordonez-Razo R, Ceballos G, Villarreal F, Ramirez-Sanchez I. Effects of (-)-epicatechin on frontal cortex DAPC and dysbindin of the mdx mice. Neurosci Lett. 2017;658:142-9.

129. McDonald CM, Ramirez-Sanchez I, Oskarsson B, Joyce N, Aguilar C, Nicorici A, Dayan J, Goude E, Abresch RT, Villarreal F, Ceballos G, Perkins G, Dugar S, Schreiner G, Henricson EK. (-)-Epicatechin induces mitochondrial biogenesis and markers of muscle regeneration in adults with Becker muscular dystrophy. Muscle Nerve. 2021;63:239-49.

130. Timpani CA and Rybalka E. Calming the (Cytokine) Storm: Dimethyl Fumarate as a Therapeutic Candidate for COVID-19. Pharmaceuticals (Basel). 2020;14.

131. Nayak S, Acharjya B. Deflazacort versus other glucocorticoids: a comparison. Indian J Dermatol. 2008;53:167-70.

\section{Publisher's Note}

Springer Nature remains neutral with regard to jurisdictional claims in published maps and institutional affiliations.

Ready to submit your research? Choose BMC and benefit from

- fast, convenient online submission

- thorough peer review by experienced researchers in your field

- rapid publication on acceptance

- support for research data, including large and complex data types

- gold Open Access which fosters wider collaboration and increased citations

- maximum visibility for your research: over $100 \mathrm{M}$ website views per year

At BMC, research is always in progress.

Learn more biomedcentral.com/submissions 